\title{
Oxidative stress, cholinesterase activity, and DNA damage in the liver, whole blood, and plasma of Wistar rats following a 28-day exposure to glyphosate
}

\author{
Mirta Milić $^{1}$, Suzana Žunec ${ }^{1}$, Vedran Micek ${ }^{1}$, Vilena Kašuba ${ }^{1}$, Anja Mikolić ${ }^{1}$, \\ Blanka Tariba Lovaković ${ }^{1}$, Tanja Živković Semren ${ }^{1}$, Ivan Pavičić1 ${ }^{1}$ \\ Ana Marija Marjanović Čermak ${ }^{1}$, Alica Pizent ${ }^{1}$, Ana Lucić Vrdoljak ${ }^{1}$, Rafael Valencia-Quintana ${ }^{2}$, \\ Juana Sánchez-Alarcón ${ }^{2}$, and Davor Želježić ${ }^{1}$ \\ Institute for Medical Research and Occupational Health, Zagreb, Croatial, Laboratorio "Rafael Villalobos-Pietrini" \\ de Toxicología Genómica y Química Ambiental, Facultad de Agrobiología, Universidad Autónoma de Tlaxcala, \\ Tlaxcala, Mexico ${ }^{2}$
}

[Received in February 2018; Similarity Check in February 2018; Accepted in June 2018]

In this 28 day-study, we evaluated the effects of herbicide glyphosate administered by gavage to Wistar rats at daily doses equivalent to 0.1 of the acceptable operator exposure level (AOEL), 0.5 of the consumer acceptable daily intake (ADI), 1.75 (corresponding to the chronic population-adjusted dose, cPAD), and $10 \mathrm{mg} \mathrm{kg}^{-1}$ body weight (bw) (corresponding to 100 times the AOEL). At the end of each treatment, the body and liver weights were measured and compared with their baseline values. DNA damage in leukocytes and liver tissue was estimated with the alkaline comet assay. Oxidative stress was evaluated using a battery of endpoints to establish lipid peroxidation via thiobarbituric reactive substances (TBARS) level, level of reactive oxygen species (ROS), glutathione (GSH) level, and the activity of glutathione peroxidase (GSH-Px). Total cholinesterase activity and the activities of acetylcholinesterase (AChE) and butyrylcholinesterase (BChE) were also measured. The exposed animals gained less weight than control. Treatment resulted in significantly higher primary DNA damage in the liver cells and leukocytes. Glyphosate exposure significantly lowered TBARS in the liver of the AOEL, ADI, and cPAD groups, and in plasma in the AOEL and cPAD group. AChE was inhibited with all treatments, but the AOEL and ADI groups significantly differed from control. Total ChE and plasma/liver ROS/GSH levels did not significantly differ from control, except for the $35 \%$ decrease in ChE in the AOEL and ADI groups and a significant drop in liver GSH in the cPAD and 100xAOEL groups. AOEL and ADI blood GSH-Px activity dropped significantly, but in the liver it significantly increased in the ADI, cPAD, and 100xAOEL groups vs. control. All these findings show that even exposure to low glyphosate levels can have serious adverse effects and points to a need to change the approach to risk assessment of low-level chronic/sub-chronic glyphosate exposure, where oxidative stress is not necessarily related to the genetic damage and AChE inhibition.

KEY WORDS: ADI; alkaline comet assay; AOEL; cholinesterase activity; cPAD; glutathione; glutathione peroxidase; lipid peroxidation; organophosphate pesticide; ROS

Organophosphorus herbicide glyphosate is a nonselective, pre- and post-emergence herbicide widely used in various agricultural and non-agricultural settings, greenhouses, aquatic and residential areas, and plant treatment plans for genetically modified, glyphosateresistant crops. As a chemical substance, this $\mathrm{N}$-(phosphonomethyl) glycine used alone or as an active ingredient in glyphosate surfactant herbicides acts as a competitor in the inhibition of 5-enolpyruvylshikimate-3phosphate synthase, a rate-limiting step in the synthesis of aromatic amino acids in the shikimate pathway in plants (1). The shikimate pathway exists in algae, archaea, bacteria, fungi, prokaryotes, and unicellular eukaryotic

Correspondence to: Mirta Milić, Mutagenesis Unit, Institute for Medical Research and Occupational Health, Ksaverska cesta 2, HR-10000 Zagreb, Croatia, e-mail:mmilic@imi.hr organisms (2-4), but is absent in animals (1), which makes glyphosate selectively toxic (5).

Glyphosate's acute oral rat $\mathrm{LD}_{50}$ is $\sim 5.6 \mathrm{~g} \mathrm{~kg}^{-1}$ of body weight per day (6). The proposed doses for general exposure were set up from hepatorenal toxicity measurements of chronic rat exposure $(5,7)$. In the European Union (EU), the acceptable daily intake (ADI) is $0.5 \mathrm{mg} \mathrm{kg}^{-1} \mathrm{bw}$ per day. (8), and the allowed concentration in the drinking water is $<0.1 \mu \mathrm{g} \mathrm{L}^{-1}(9)$ and in food $0.01-5 \mathrm{mg} \mathrm{kg}^{-1}(8)$. For fish tissue consumed by humans (10) there are no recommended limits, as glyphosate degrades quickly in soil or water and poorly bioaccumulates in fish. In the USA, the ADI is $1.75 \mathrm{mg} \mathrm{kg}^{-1}$ (11), whereas the allowed concentration in drinking water is $700 \mu \mathrm{g} \mathrm{L}^{-1}$ (12). A big debate about its safe use has been going on since 2010 due to these considerable regulatory discrepancies about possible 
harmful effects of glyphosate. Some regulatory bodies reclassified glyphosate as probably carcinogenic to humans (Group 2A) (World Health Organization - International Agency for Research on Cancer, WHO-IARC) $(13,14)$, but also as unlikely to be carcinogenic (European Food Safety Authority, EFSA) (15) or pose carcinogenic risk to humans from exposure through diet (Food and Agriculture Organization, FAO-WHO) (16). European Chemicals Agency (ECHA) classified glyphosate as causing serious eye damage and being toxic to aquatic life with long-lasting effects (17). In contrast, the US Environmental Protection Agency (EPA) reclassified glyphosate from the least toxic (category IV) substrate for animals (18) into practically non-toxic and not an irritant. According to the EU assessment (8), glyphosate is among the $10 \%$ of herbicides with a higher ADI in long-term dietary exposure and slightly more toxic in short-term dietary exposure $\left(45^{\text {th }}\right.$ percentile) than is the average for herbicides. Information about glyphosate ranking and percentile among about 150 herbicides assessed in the EU gives an indication of glyphosate toxicity to humans relative to other herbicides and is based on acute risk assessment (Acute Reference Dose, ARfD) in addition to ADI, which are in this case the same values of $0.5 \mathrm{mg} \mathrm{kg}^{-1}$ bw per day (19).

A growing number of studies has demonstrated nontarget effects on mammalian metabolism at low, environmentally relevant levels. In vitro research evidences that glyphosate levels in the range of human population exposure can affect mammalian mitochondrial function by disrupting liver mitochondrial oxidative phosphorylation (20-22), by increasing mitochondrial membrane permeability for protons and calcium ions (22), and by inhibiting succinate dehydrogenase (23). Glyphosate can also trigger oxidative stress and cause oxidative damage to lipids, proteins, and DNA (24), especially in erythrocyte and lymphocyte cell membranes (25). It can affect glutathione, aromatase (26) and antioxidant enzyme levels, such as superoxide dismutase (SOD), catalase, glutathione peroxidase (GSH-Px), and glutathione reductase (27-30), and can inhibit acetylcholinesterase (AChE) activity (28, 29, 31).

Short-term studies in rodents did not demonstrate apparent toxic effect (32). Lifelong exposure demonstrated liver and kidney dysfunction and toxicity (33), deficiencies in foetal ossification in pregnant rats (34), a greatly increased risk of cancer, and shorter lifespan (13). A twoyear rat study (35) demonstrated changes in urine and organ biochemical parameters as well as in proteomic and metabolomic profile (35). Although the toxicity of glyphosate can be both dose- and species-dependent (36) - aquatic organisms seem to be more sensitive-new studies shift their concern from acute to chronic, sub-chronic, and reproductive toxicity, as more relevant (37).

Our knowledge of glyphosate toxicokinetics is based on rat studies by the Monsanto Company (38-40), the US National Toxicology Program (41), glyphosate-derived radioactivity tissue studies $\left(10 \mathrm{mg} \mathrm{kg}^{-1}\right.$ or higher dose treatment) $(42,43)$, and reviews by Williams et al. $(9,14$, $15,19,44,45)$ of the carcinogenicity studies conducted by the IARC, EFSA, and EPA. With knowledge this limited, we need to go further to investigate the toxicokinetic profile of glyphosate with multiple doses, ranging between low and high for mechanistic understanding and key events in the biological pathways as well as time- or dosedependencies (45). The reason for looking into low doses is the new evidence of harmful effects $(2,35,46,47)$, which gets worse with sub-chronic and chronic exposure $(35,37)$. Glyphosate traces found in human urine and blood of agricultural and non-agricultural workers, pregnant women and children $(2,14,48-52)$ point to a higher risk of longterm environmental exposure (53).

Based on the evidence from these new studies and our own evidence (46), we decided to look further into the toxicological mechanisms and effects of sublethal, environmentally relevant (yet allegedly human-safe) glyphosate doses in rats to see how they affect: (a) body weight and liver weight, (b) cholinesterase (ChE), AChE, and butyrylcholinesterase (BChE) activities, (c) oxidative stress markers (lipid peroxidation, reactive oxygen species, GSH, and GSH-Px), and (d) the levels of primary DNA damage in leukocytes and small and medium-sized liver cells, all of which are the established markers of glyphosate mechanisms and effects.

\section{MATERIALS AND METHODS}

\section{Chemicals and reagents}

All of the chemicals were of analytical grade and purchased from Sigma-Aldrich Chemical Co. (St. Louis, MO, USA), unless otherwise specified. Glyphosate (CAS No. 1071-83-6) was of analytical standard purity grade $(\leq 100 \%)$, purchased under the brand name PESTANAL ${ }^{\circledR}$, a registered trademark of Sigma-Aldrich Laborchemikalien GmbH (Germany).

\section{Animals}

Animal procedures and protocols were carried according to internationally accepted animal welfare guidelines, and the study was approved by the Ethics Committee of the Institute for Medical Research and Occupational Health (IMROH), Zagreb, Croatia. For the experiments we used 30 male Wistar rats obtained from the breeding unit at IMROH. They were kept under pathogenfree, steady-state microenvironmental conditions in clear polycarbonate cages with $40-60 \%$ humidity at $22{ }^{\circ} \mathrm{C}$ and normal 12-hour light/dark cycle. The animals had free access to standard Good Laboratory Practice-certified food (Mucedola, 4RF21, Italy) and tap water. When they were three months old, the rats were weighted, inspected, and 
judged to be healthy and fit for the experiment by a licensed veterinarian at IMROH.

\section{Experimental design}

Stock glyphosate solution was prepared in phosphatebuffered saline (PBS). The tested doses included environmentally relevant exposure levels usually not harmful to humans, more specifically, the EFSA's acceptable operator exposure level (AOEL) of $0.1 \mathrm{mg} \mathrm{kg}^{-1}$ bw per day (54) and the acceptable daily intake (ADI) for consumers of $0.5 \mathrm{mg} \mathrm{kg}^{-1}$ bw per day (9), the EPA's chronic population-adjusted dose (cPAD) of $1.75 \mathrm{mg} \mathrm{kg}^{-1}$ bw per day (11), and the 100 times the AOEL, which is $10 \mathrm{mg} \mathrm{kg}^{-1}$ bw per day (100xAOEL).

Ethyl methanesulphonate (EMS) served as positive control, being a well-established genotoxicant recommended for in vivo comet assay in rodents (55), which was also dissolved in PBS.

Male Wistar rats were randomly divided into six groups of five animals receiving $1 \mathrm{~mL}$ of PBS (with or without glyphosate) by oral gavage. The control group received $1 \mathrm{~mL}$ of PBS at room temperature throughout the experiment. The positive control group received EMS (300 $\mathrm{mg} \mathrm{kg}^{-1} \mathrm{bw}$ ) over the last three days of the experiment. The AOEL, ADI, cPAD, and 100xAOEL groups received glyphosate in the above described doses.

Body weight was monitored once a week and the glyphosate doses adjusted accordingly. Survival and clinical signs of poisoning were also monitored on a daily basis.

The treatment lasted 28 days. All animals were humanely euthanised and dissected on day 29, $24 \mathrm{~h}$ after the last dose. Euthanisation was performed by exsanguination under Xylapan/Narketan anaesthesia (Xylapan, Vetoquinol UK Ltd., $12 \mathrm{mg} \mathrm{kg}^{-1}$ bw, i. p./Narketan, Vetoquinol UK Ltd., $80 \mathrm{mg} \mathrm{kg}^{-1} \mathrm{bw}$ ) directly from the heart. Immediately after euthanasia, all animals were examined for gross pathological changes of the internal organs. To calculate relative liver weight, we used the following formula:

ROW (relative organ weight $)=\frac{\text { absolute organ weight }(\mathrm{g})}{\mathrm{BW}(\text { body weight })(\mathrm{g})} * 100 \%$

where body weight was measured moments before and the absolute liver weight after euthanasia.

\section{Sample collection and preparation}

All samples were taken immediately after euthanasia. Liver was removed from the abdomen, rinsed with cold PBS at $\mathrm{pH} 7.4$, and weighed. Liver was then washed in cold TBS buffer (50 mmol L-1 Tris-Cl, $150 \mathrm{mmol} \mathrm{L}^{-1} \mathrm{NaCl}, \mathrm{pH}$ 7.5) (56) to remove as much blood as possible, homogenised in a $50 \mathrm{mmol} \mathrm{L}^{-1}$ potassium PBS pH 7.4 with $1 \mathrm{mmol} \mathrm{L}^{-1}$ EDTA (1 mL of buffer to $100 \mathrm{mg}$ of tissue), and centrifuged at $20,000 \mathrm{x} g$ at $4{ }^{\circ} \mathrm{C}$ for $30 \mathrm{~min}$ to obtain the supernatant.

In a separate procedure, a small portion of the liver tissue was minced in a chilled mincing solution $\left(75 \mathrm{mmol} \mathrm{L}^{-1}\right.$
$\mathrm{NaCl}, 24$ mmol L-1 $\mathrm{Na}_{2}$ EDTA, $\mathrm{pH}$ 7.5) (56) to obtain cellular suspension. Individual cells were separated with a pair of fine scissors. The cell suspension was left a few seconds for large clumps to settle, and the supernatant was used to prepare comet slides. All this was performed within $60 \mathrm{~min}$ from death to avoid confounding necrotic changes.

Blood samples were collected directly from the heart into heparinised vacutainers (Becton Dickinson, Franklin Lakes, NJ, USA) with an extra addition of Li-heparin, mixed vigorously to prevent clumping. Samples were then refrigerated at $4{ }^{\circ} \mathrm{C}$ until further processing. For biochemical assays, heparinised blood was centrifuged at $976 \mathrm{x} \mathrm{g}$ and $4{ }^{\circ} \mathrm{C}$ for $10 \mathrm{~min}$ to remove plasma and then frozen at $-20^{\circ} \mathrm{C}$ until further processing.

Assessment of primary DNA damage with alkaline comet assay in blood and small and medium sized liver cells

Two microgels were prepared per tissue per animal. Slides were marked with a randomly generated code. For each slide, an aliquot of $10 \mu \mathrm{L}$ of the cell suspension was mixed with low melting point agarose (LMPA) (0.5\%) dissolved in TBS buffer. "Sandwich" agarose microgels made of four layers were prepared on microscopic slides. Slides were pre-coated with $1 \%$ normal melting point agarose (NMPA) (Sigma) and air-dried. The second gel layer of $0.6 \%$ NMP agarose was then applied. The third layer consisted of a $0.5 \%$ LMPA mixed with heparinised whole blood $(10 \mu \mathrm{L}$ per slide) or $10 \mu \mathrm{L}$ of liver cell suspension per slide. Finally, $0.5 \%$ LMPA was applied as the top layer over the gel-embedded cells.

After solidification of the gel on ice-cold metal tray, the slides were submerged in freshly prepared cold lysing solution (100 mmol L-1 EDTA, $2.5 \mathrm{~mol} \mathrm{~L}^{-1} \mathrm{NaCl}, 10 \mathrm{mmol} \mathrm{L}^{-1}$ Tris-Cl, pH 10, $1 \%$ of Triton-X 100 and $10 \%$ DMSO) at $4{ }^{\circ} \mathrm{C}$ overnight. The slides were quickly washed with distilled water and left in a vertical Coplin jar with chilled electrophoresis buffer $\left(300 \mathrm{mmol} \mathrm{L}^{-1} \mathrm{NaOH}, 1 \mathrm{mmol} \mathrm{L}^{-1}\right.$ $\mathrm{Na}_{2}$ EDTA, $\mathrm{pH}>13$ ) at $4{ }^{\circ} \mathrm{C}$ for $10 \mathrm{~min}$. The slides were then transferred into a horizontal electrophoresis unit. The liver samples were electrophoresed at $1 \mathrm{~V} \mathrm{~cm}^{-1}$ and constant current of $300 \mathrm{~mA}$ for $10 \mathrm{~min}$ (56), and the blood samples at $0.86 \mathrm{~V} \mathrm{~cm}^{-1}$ and constant current of $300 \mathrm{~mA}$ for $20 \mathrm{~min}$ (57). After electrophoresis, the slides were washed three times with neutralisation buffer $\left(0.4 \mathrm{~mol} \mathrm{~L}^{-1}\right.$ Tris- $\mathrm{HCl}, \mathrm{pH}$ 7.5). All gels were dehydrated with $70 \%$ and $96 \%$ ethanol, respectively, air dried, and stored at room temperature.

Before scoring, the slides were stained with ethidium bromide $\left(20 \mu \mathrm{g} \mathrm{mL}^{-1}\right)$ and analysed with a fluorescent microscope under 200x magnification (Olympus BX50, Olympus, Tokyo, Japan) using the Comet Assay IV image analysis system (Instem-Perceptive Instruments Ltd., Suffolk, Halstead, UK) equipped with appropriate filters. Three hundred cells ( 2 x 150 nucleoids) were scored in total for each animal and sample. Medium-sized cells (parenchymal cells or hepatocytes, between 30 and $40 \mu \mathrm{m}$ 
of head length) and small-sized cells (non-parenchymal cells, $<30 \mu \mathrm{m}$ of head length) were recorded separately (58).

Areas near slide margins were not scored. DNA damage was measured as comet DNA tail intensity ( $\%$ of DNA in tail) and tail length (TL, expressed in $\mu \mathrm{m}$, measured from the estimated edge of the comet head).

Comets with small or non-existing head and large, diffuse tails (cells with $>80 \%$ DNA in the tail) were excluded from analysis. The frequency of such comets ("hedgehogs" or "clouds") was determined based on visual scoring among 100 nucleoids per sample. According to literature data, they may represent DNA damage resulting from cytotoxicity (59). We did not measure the abnormalsized tail parameters, as we find them inappropriate for this study.

\section{ROS detection}

ROS levels in blood plasma and liver homogenates were measured using 2',7'-dichlorofluorescein diacetate (DCFDA). The acetate group of 2'-7'- dichlorodihydrofluorescein diacetate (DCFH-DA) gets DCFH-DA into the cells or organelles, and once inside, it is removed by cellular esterases, producing reduced DCFH which then can be oxidised by peroxides to form fluorescent oxidised DCF that can be measured spectrophotometrically. Plasma samples and $1 \%$ liver tissue homogenate were prepared by dilution with ice-cold PBS (pH 7.4). Black 96-well plates were filled with $0.07 \mathrm{~mL}$ of PBS, and $0.03 \mathrm{~mL}$ of $1 \%$ liver tissue homogenate or with $0.1 \mathrm{~mL}$ of $10 \%$ blood plasma in quintuplicate for each glyphosate concentration and sample type. Each well was then added $20 \mu \mathrm{L}$ of $0.12 \mathrm{mmol} \mathrm{L}^{-1}$ DCFH-DA dye in PBS, and the plates were incubated at $37{ }^{\circ} \mathrm{C}$ for $30 \mathrm{~min}$. Control for dye autofluorescence was prepared without the addition of dye. Control samples were included in each experiment. Samples were analysed using a Victor $3^{\mathrm{TM}}$ (PerkinElmer, Inc. Waltham, MA, USA) multilabel plate reader at an excitation wavelength of $485 \mathrm{~nm}$ and emission wavelength of $535 \mathrm{~nm}$. The readings were expressed as relative fluorescence units (RFU).

\section{Determination of lipid peroxidation in plasma and liver}

The concentrations of thiobarbituric reactive substances (TBARS), as a measure of lipid peroxidation, were determined using a modified method by Drury et al. (1997) (60). Butylated hydroxytoluene (BHT; $5 \mu \mathrm{L} ; 0.2 \%$; w/v) and phosphoric acid $(750 \mu \mathrm{L} ; 1 \%$; v/v) were added to $50 \mu \mathrm{L}$ of sample. After mixing, $250 \mu \mathrm{L}$ of $0.6 \%$ (w/w) thiobarbituric acid (TBA) and $445 \mu \mathrm{L}_{2} \mathrm{H}_{2} \mathrm{O}$ were added, and the reaction mixture was incubated in a water bath at $90{ }^{\circ} \mathrm{C}$ for $30 \mathrm{~min}$. The mixture was cooled, and absorbance measured at $532 \mathrm{~nm}$ on a Shimadzu UV probe spectrophotometer (Shimadzu Corporation, Kyoto, Japan). TBARS concentrations were calculated using the standard curves for 1,1,3,3-tetramethoxypropane, obtained by increasing its concentrations, and expressed as $\mu \mathrm{mol} \mathrm{L}^{-1}$.

\section{Quantification of GSH}

GSH levels were analysed with a fluorogenic bimane probe using monochlorobimane $(\mathrm{MBCl})$, which reacts specifically with GSH to form a fluorescent adduct (61). Plasma samples and liver tissue homogenates were prepared as previously described for ROS measurement and then added $20 \mu \mathrm{L}$ of $0.24 \mathrm{mmol} \mathrm{L}^{-1} \mathrm{MBCl}$ dye in PBS to react at $37{ }^{\circ} \mathrm{C}$ for $20 \mathrm{~min}$. The amount of GSH in the samples was analysed using a Victor $3^{\mathrm{TM}}$ multilabel plate reader at an excitation wavelength of $355 \mathrm{~nm}$ and emission wavelength of $460 \mathrm{~nm}$. Control samples were included in each experiment. The readings were expressed as relative fluorescence units (RFU). Each sample analysis was performed in quintuplicate.

\section{Determination of GSH-Px activity in whole blood and liver}

GSH-Px activity in whole blood and the supernatant of liver homogenate were determined in accordance with the European standardized method (62). The amount of GSH oxidised by t-butyl hydroperoxide was determined based on decrease in $\beta$-NADPH absorbance at $340 \mathrm{~nm}$, measured by spectrophotometry (Cary 50 UV-Vis, Varian Inc., Santa Clara, CA, USA). One unit of GSH-Px was the number of micromoles of $\beta$-NADPH oxidised per minute. Its activity in whole blood was expressed per gram of haemoglobin $\left(\mathrm{U} \mathrm{g}_{\mathrm{Hb}}{ }^{-1}\right)$, and in the liver homogenate per gram of total protein $\left(\mathrm{Ug}_{\text {protein }^{-1}}\right)$.

\section{Protein quantification}

Proteins were quantified according to the method of Bradford (1976), using bovine serum albumin as standard (63).

\section{Determination of plasma cholinesterase activity}

Plasma samples were analysed for total ChE, AChE, and $\mathrm{BChE}$ activities in a $0.1 \mathrm{~mol} \mathrm{~L}^{-1}$ sodium phosphate buffer, $\mathrm{pH} 7.4$, at $25^{\circ} \mathrm{C}$ using ATCh $\left(1.0 \mathrm{mmol} \mathrm{L}^{-1}\right)$ and DTNB $\left(0.3 \mathrm{mmol} \mathrm{L}^{-1}\right)$ as described by Ellman et al. (64). To distinguish between $\mathrm{AChE}$ and $\mathrm{BChE}$ activities we used the BChE-selective inhibitor ethopropazine $\left(20 \mu \mathrm{mol} \mathrm{L}^{-1}\right)$. Increase in absorbance was monitored at $412 \mathrm{~nm}$ over $4 \mathrm{~min}$. All of the measurements were performed on a Cecil 9000 spectrophotometer (Cecil Instruments Limited, Cambridge, $\mathrm{UK})$. Enzyme activities were expressed as IU $\mathrm{g}_{\text {protein }}{ }^{-1}$.

\section{Statistical analysis}

Statistical analysis was run on Dell Statistica software STATISTICA, version 13.2 (Dell Inc., Round Rock, TX, USA). The data were first evaluated with descriptive statistics. The results were expressed as means \pm standard 
deviation, and for the comet assay we also used medians and ranges (min-max).

Relative liver weights were logarithmically transformed $\left[\log _{10}(\mathrm{~N}+2)\right]$ and analysed with one-way ANOVA. For pairwise organ comparison we used the post-hoc Tukey's HSD test.

Normality of (Gaussian) distribution was tested with the Levene's test. Since the results of the alkaline comet assay were not normally distributed even after logarithmic transformation, we used the non-parametric Mann-Whitney U test.

For multiple comparisons of cholinesterase activities, TBARS, and GSH-Px activities between the glyphosate and control groups we used the Kruskal-Wallis test. ROS and GSH levels were compared between the groups using the non-parametric Mann-Whitney U test. P values $\leq 0.05$ were considered statistically significant.

\section{RESULTS AND DISCUSSION}

\section{Changes in body and liver weight}

The 28-day treatment with different glyphosate doses did not cause premature death or any sign of systemic toxicity in the male adult Wistar rats. Throughout the treatment, and especially on weighting days, our trained veterinary observed the animals for the presence of miosis, mouthsmacking, salivation, or lacrimation, tremors, or gait abnormalities, as described elsewhere (65), and found no significant differences between controls and treated animals, except in body weight gain. Gross necropsy did not reveal any treatment-related findings.

Figure 1 shows body weight changes and Figure 2 demonstrates relative liver weight across the groups over the 28 days of treatment. All glyphosate-treated animals had similar weight gain through the 28-day treatment, with significant difference between the body mass on the day before the treatment and the end of treatment. On the last day, only the cPAD and the 100xAOEL group showed gain. However, it did not differ significantly between the groups.

The existing literature suggests that glyphosate treatment affects the growth of rats. Tang et al. (66) observed lower body weight gain in adult male rats after 35 days of treatment with glyphosate at the daily doses of 5-500 $\mathrm{mg} \mathrm{kg}^{-1}$ bw. Liver weight changes upon glyphosate treatment have also been demonstrated in many studies (as reviewed in 13). The US EPA suggested that they depended on glyphosate concentration and rodent species (5). However, there are also studies that demonstrated no changes $(67,68)$ or even pointed to an increase in liver weight (41). This increase could be connected with the non-alcoholic fatty liver disease and its progression to non-alcoholic steatohepatosis, as reported by Mesnage et al. (35) and Samsel and Senef (2).

\section{Alkaline comet assay}

Table 1 shows the results of the alkaline comet assay in leukocytes and liver cells with small and medium-sized nuclei.

Glyphosate-treated rats had higher primary DNA damage in leukocytes compared to control in both comet assay parameters. While tail length was significantly greater after all treatments, only the lowest tested dose resulted in significantly higher mean tail intensity. One reason for that could be high standard deviations.

Worth noticing is that glyphosate caused greater DNA damage in the liver cells than in the leukocytes (Table 1). Since liver is a complex organ with multiple cells working

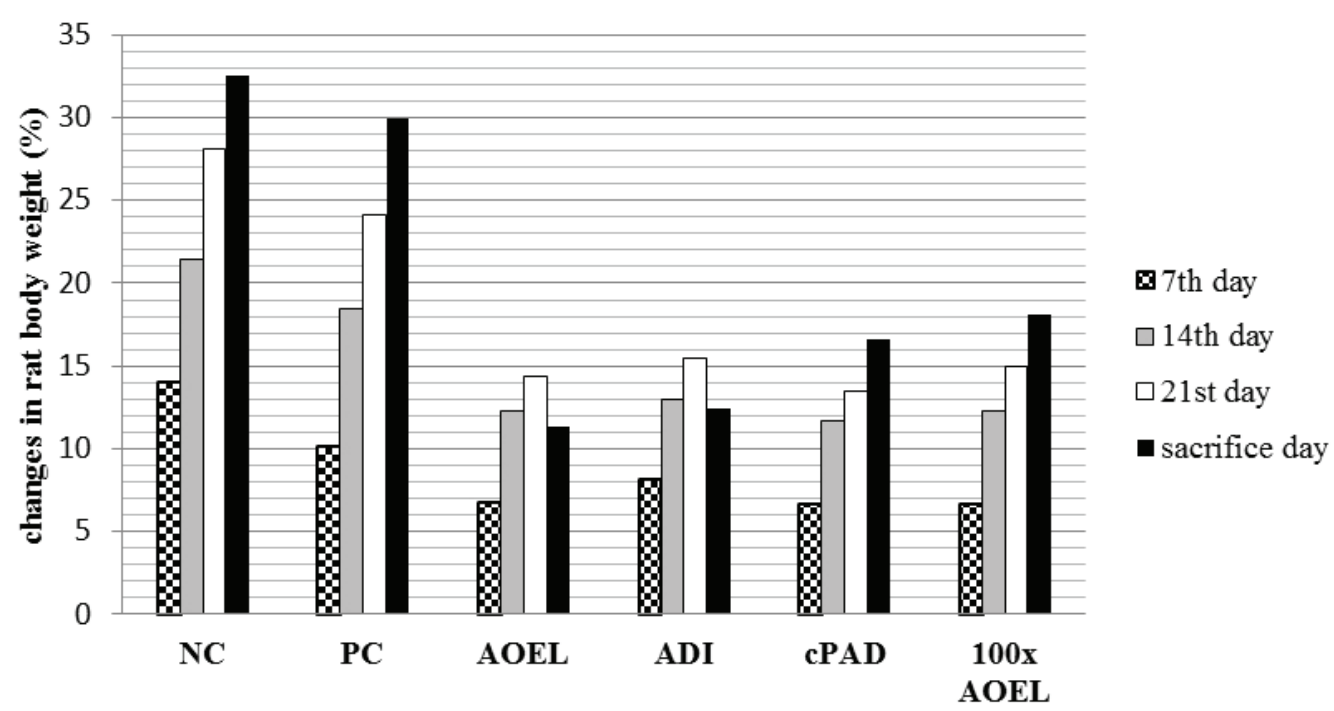

Figure 1 Changes in the percentage of the body weight gain in Wistar rats ( $N=5$ per group) on the $7^{\text {th }}, 14^{\text {th }}, 21^{\text {st }}$, and $28^{\text {th }}$ day of treatment with different doses of glyphosate in PBS. $N C$-negative control receiving $1 \mathrm{~mL}$ of PBS; $P C$ - positive control receiving $300 \mathrm{mg} \mathrm{kg}^{-1} \mathrm{bw}$ day ${ }^{-1}$ of ethyl methanesulphonate last three days of treatment; AOEL - acceptable operator exposure level $\left(0.1 \mathrm{mg} \mathrm{kg}^{-1} \mathrm{bw} \mathrm{day}^{-1}\right)$; ADI - acceptable daily intake for consumers $\left(0.5 \mathrm{mg} \mathrm{kg}^{-1} \mathrm{bw}\right.$ day-1); cPAD - chronic population adjusted dose $\left(1.75 \mathrm{mg} \mathrm{kg}^{-1} \mathrm{bw} \mathrm{day}\right.$ $\left.{ }^{1}\right) ; 100 x A O E L-100$ times the AOEL (10 $\mathrm{mg} \mathrm{kg}^{-1} \mathrm{bw} \mathrm{day^{-1 } )}$ 


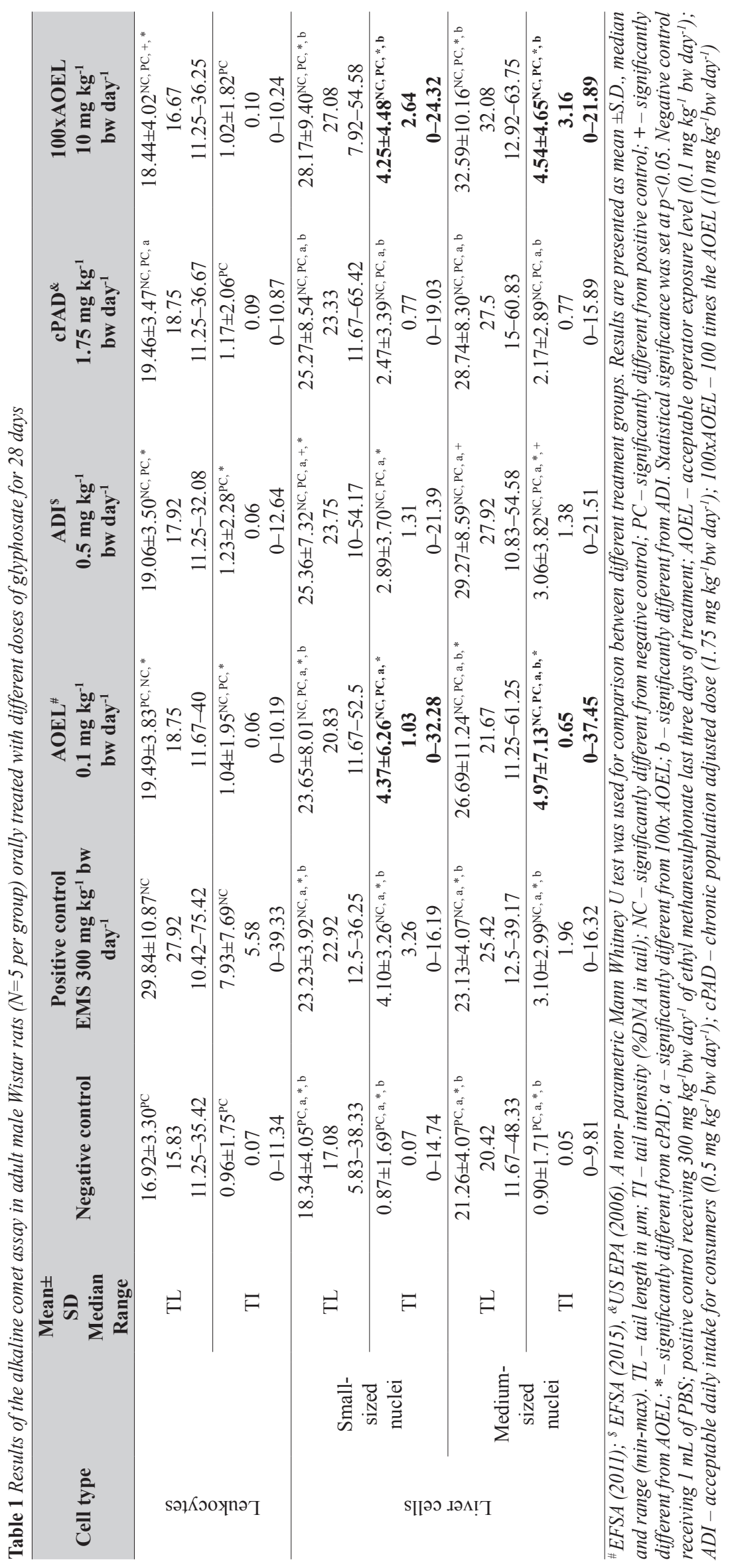




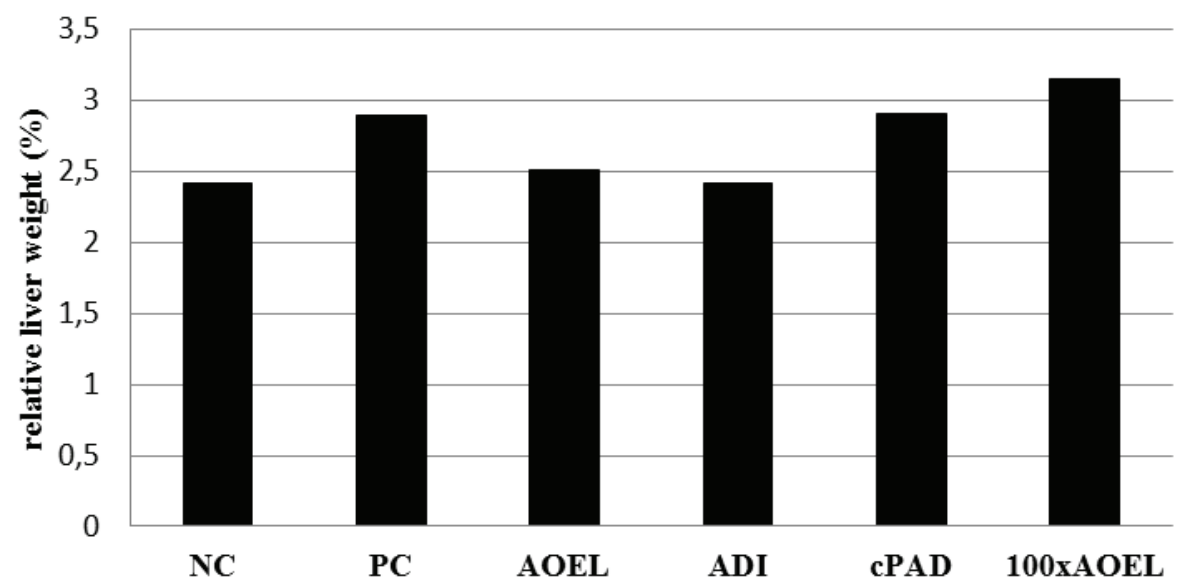

Figure 2 Changes in the relative liver weight of Wistar rats $(N=5$ per group) treated with different doses of glyphosate orally for 28 days according to the ROW formula. NC-negative control receiving $1 \mathrm{~mL}$ of PBS; $P C$ - positive control receiving $300 \mathrm{mg} \mathrm{kg}^{-1}$

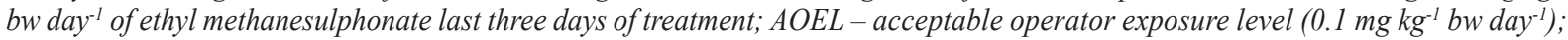
ADI - acceptable daily intake for consumers $\left(0.5 \mathrm{mg} \mathrm{kg}^{-1} \mathrm{bw}\right.$ day-1 $c P A D$ - chronic population adjusted dose $\left(1.75 \mathrm{mg} \mathrm{kg}^{-1} \mathrm{bw} \mathrm{day}^{-1}\right)$; 100xAOEL - 100 times the AOEL $\left(10 \mathrm{mg} \mathrm{kg}^{-1} \mathrm{bw}\right.$ day $\left.^{-1}\right)$

together in cohesion, two cell types should be taken into account to obtain reliable information about the toxic effects of the tested compound at the DNA level. Parenchymal cells or hepatocytes (medium-sized nuclei) account for $80 \%$ of the cells in the liver and are primarily responsible for drug metabolism. Non-parenchymal cells (small-sized nuclei) have many specific functions in the liver and contribute to inflammatory responses. Differences in the responses of the two cell populations to treatments (Table 1) could be associated with their intrinsic variations in DNA sensitivity.

Interestingly, the greatest liver cell DNA damage (judged by tail intensity) occurred with the lowest and the highest exposure both in parenchymal and non-parenchymal liver cells. In fact, the 100xAOEL group suffered even greater damage in medium-sized liver cells than positive control.

Our findings are in line with previous comet assay in vitro and in vivo animal studies with glyphosate, which reported its damaging potential for the DNA. In one study (69), in vitro treatment of human lymphocytes with 0.7 $700 \mu \mathrm{mol} \mathrm{L}-1$ of glyphosate led to a significant increase in tail length. In another study (70), exposure of non-dividing human lymphocytes to $0.5-580 \mu \mathrm{g} \mathrm{mL}^{-1}$ of glyphosate along with metabolic activation resulted in a significant increase in tail intensity only at $580 \mu \mathrm{g} \mathrm{mL}^{-1}\left(\sim 3.4 \mathrm{mmol} \mathrm{L}^{-1}\right)$, as established with the alkaline comet assay (70). The same authors reported a dose-related increase in tail length measured with the hOGG1-modified comet assay. In a study using Hep-2 cells, Manas et al. (71) reported a significant increase in mean tail length and tail intensity at the concentration range of 3.0-7.5 $\mathrm{mmol} \mathrm{L}^{-1}$ of glyphosate.

Rats exposed to glyphosate at the doses of $5-490 \mathrm{mg} \mathrm{kg}^{-1}$, administered every $48 \mathrm{~h}$ for 75 days, demonstrated irreversible damage to hepatocytes (34). In another study (68), mild liver damage was reported in rats following subchronic exposure to glyphosate (56 and $560 \mathrm{mg} \mathrm{kg}^{-1}$ ) for 35 and 90 days.
Several comparable studies were conducted in mice. Mice receiving 40 and $400 \mathrm{mg} \mathrm{kg}^{-1}$ bw of glyphosate per day via drinking water demonstrated a significant increase in primary DNA damage in blood and liver cells after a 14-day exposure. Since no effects on oxidative stress parameters were observed, the authors suggested that DNA damage may not be related to oxidative damage.

Bolognesi et al. (73) showed DNA damage in mice exposed intraperitoneally (i.p.) to a single $300 \mathrm{mg} \mathrm{kg}^{-1}$ dose of glyphosate. Single strand DNA breaks increased in the liver and kidney $4 \mathrm{~h}$ after the injection, but they returned to control levels on hour 24. Similar effects in mice were seen for high i.p. doses (41).

El Shenawy et al. (67) showed that cellular injury occurred with millimolar glyphosate doses given over longer time due to cumulative effects.

Speaking about the types of DNA damage induced by glyphosate treatments, Bolognesi et al. (73) demonstrated $8-\mathrm{OHdG}$ in the liver of mice following single i.p. injection of $300 \mathrm{mg} \mathrm{kg}^{-1}$ of glyphosate. Peluso et al. (74) reported that technical glyphosate did not form DNA adducts in the liver or kidney of mice injected up to $270 \mathrm{mg} \mathrm{kg}^{-1}$ i.p.

Greim et al. in their review article (75) point to the essential role of glycine in glyphosate-mediated DNA damage, more specifically in distinguishing 8-oxoG from guanine at position G42. Glyphosate substitution for glycine can impair the function of OGG1 (75) and thus trigger a cascade of consequences, starting with the accumulation of unrepaired 8-oxoG and clustering of DNA damage and double-strand breaks (visible by the comet assay) and resulting in chromatid deletions and achromatic lesions, as already reported by Monsanto in 1983 (as reviewed in 75).

\section{Oxidative stress markers}

Several studies (27-30) have demonstrated that glyphosate or glyphosate-based herbicide exposure affects 


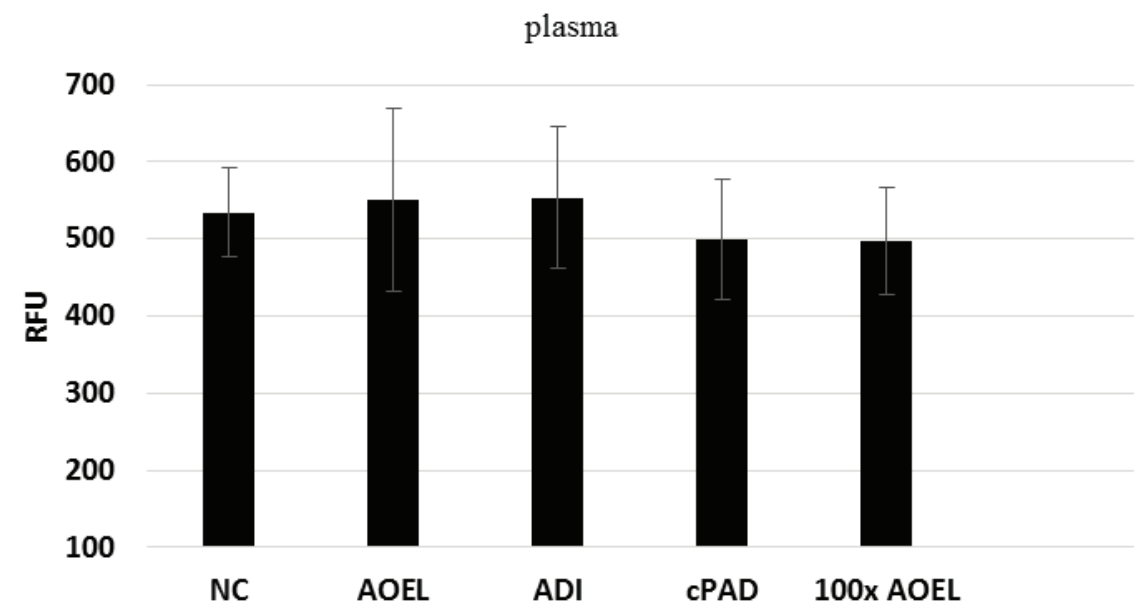

Figure 3a ROS in the plasma of Wistar rats treated with different doses of glyphosate orally for 28 days

$R F U$-relative fluorescence units; $N C$-negative control receiving $1 \mathrm{~mL}$ of PBS; AOEL-acceptable operator exposure level $\left(0.1 \mathrm{mg} \mathrm{kg}{ }^{-1}\right.$ bw day-1); ADI-acceptable daily intake for consumers $\left(0.5 \mathrm{mg} \mathrm{kg}^{-1} \mathrm{bw}\right.$ day-1); cPAD - chronic population adjusted dose $(1.75 \mathrm{mg} \mathrm{kg}$ ${ }^{1} \mathrm{bw}$ day $\left.^{-1}\right)$; 100xAOEL - 100 times the AOEL $\left(10 \mathrm{mg} \mathrm{kg}^{-1} \mathrm{bw} \mathrm{day}^{-1}\right)$

indicators of oxidative stress. Our study in general (Figures 3-6) did not reveal significant disturbances of the oxidative stress markers at the tested doses nor has it pointed to dosedependency.

\section{ROS levels in plasma and liver}

Plasma samples (Figure 3a) did not demonstrate any significant difference between the glyphosate groups and control. A small drop in ROS of around $7 \%$ (compared to the control) is still visible in the groups exposed to the highest glyphosate doses. The liver tissue showed a similar pattern (Figure 3b), but ROS levels in the liver were 100 times greater than in the plasma and the drop in 100xAOEL group was significant compared to control.

\section{Lipid peroxidation}

Figure 4 shows that the TBARS concentrations in the plasma and liver dropped in all glyphosate-treated groups compared to control. It also details how significant these changes were between groups.

\section{GSH levels in plasma and liver}

Plasma samples showed no significant difference between the treated groups and control, even though GSH was higher in the two groups treated with the highest doses (6.82 \% and $12.29 \%$, respectively). In the liver, GSH dropped in all treated groups, but the difference from control was significant only in the cPAD and 100xAOEL group (22.72, and $26.92 \%$, respectively) (Figure 5).

liver

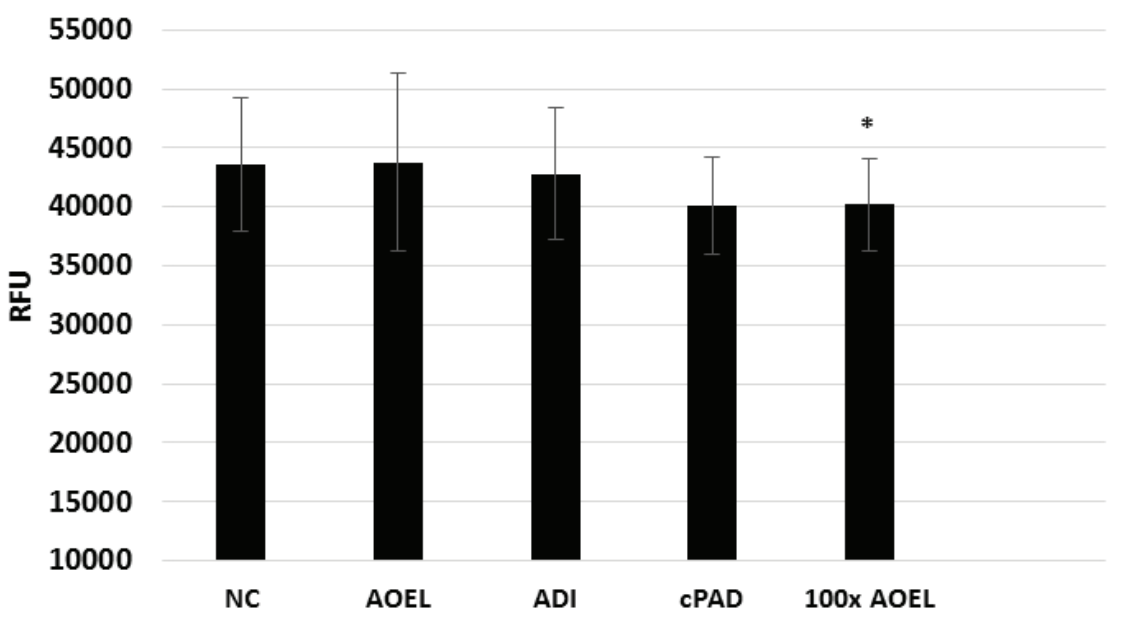

Figure 3b ROS in the liver tissue of Wistar rats treated with different doses of glyphosate orally for 28 days

$R F U-$ relative fluorescence units. Statistical significance was set at $p<0.05$. *Significantly different from the negative control. NC negative control receiving $1 \mathrm{~mL}$ of PBS; AOEL - acceptable operator exposure level $\left(0.1 \mathrm{mg} \mathrm{kg}^{-1} \mathrm{bw} \mathrm{day-1}\right) ; A D I$ - acceptable daily

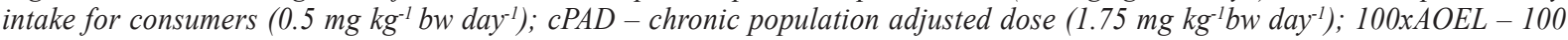
times the AOEL (10 $\mathrm{mg} \mathrm{kg}^{-1} \mathrm{bw}$ day-1) 


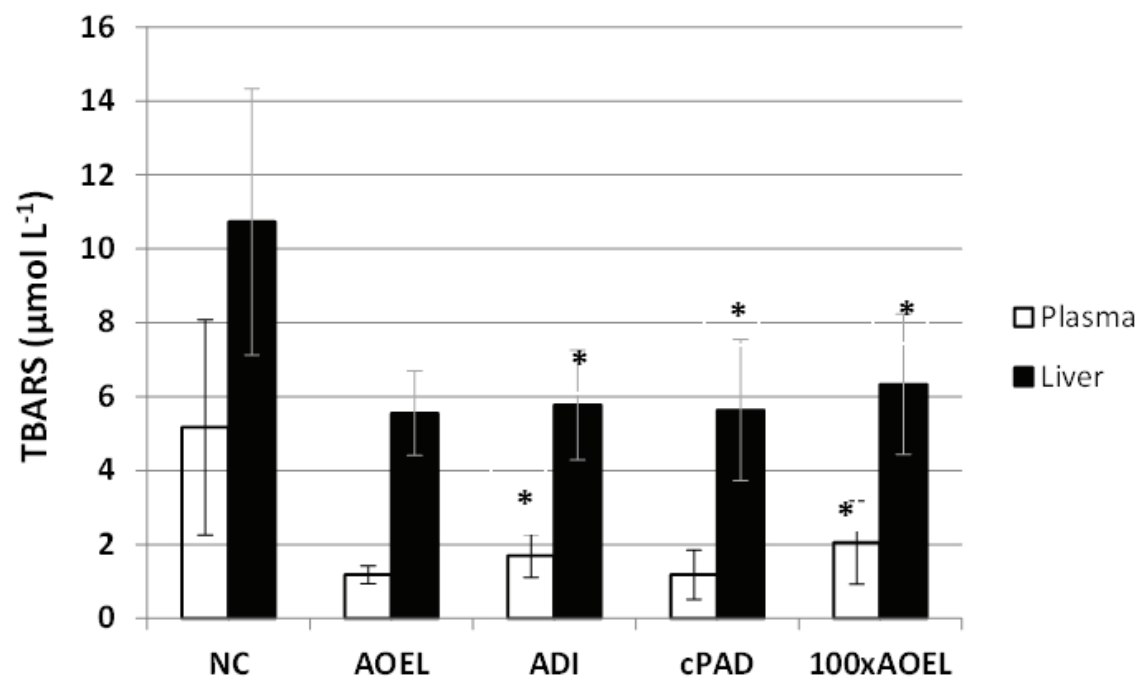

Figure 4 Changes in TBARS concentration in the plasma and liver of Wistar rats after the 28-day treatment with different glyphosate doses. The results are shown as mean and $S D$ values. Significantly different values $(P<0.05)$ were: $(*)$ compared to control. NC negative control receiving $1 \mathrm{~mL}$ of PBS; AOEL - acceptable operator exposure level ( $0.1 \mathrm{mg} \mathrm{kg}^{-1} \mathrm{bw}$ day-1); ADI-acceptable daily intake for consumers $\left(0.5 \mathrm{mg} \mathrm{kg}^{-1} \mathrm{bw}\right.$ day $\left.\mathrm{y}^{-1}\right) ; \mathrm{cPAD}$ - chronic population adjusted dose $\left(1.75 \mathrm{mg} \mathrm{kg}^{-1} \mathrm{bw} \mathrm{day-1}^{-1}\right) ; 100 x A O E L-100$ times the AOEL $\left(10 \mathrm{mg} \mathrm{kg}^{-1} \mathrm{bw} \mathrm{day}^{-1}\right)$

\section{GSH-Px activity in whole blood and liver}

Blood GSH-Px activity was significantly lower in the AOEL and ADI groups than in control (Figure 6). Its liver activity, in turn, was significantly higher in the ADI, cPAD, and 100xAOEL group.

Literature associates elevated levels of oxidative stress with exposure to high glyphosate doses (71), which means higher bioavailability, relatively high glyphosate plasma concentrations over a short time, slower distribution/ elimination from the plasma to the organs, followed by ROS generation that depletes the antioxidants already present in the body and induces additional production of antioxidants and antioxidant enzyme activity. Higher ROS and higher defence enzyme activities would be expected in the liver,

plasma

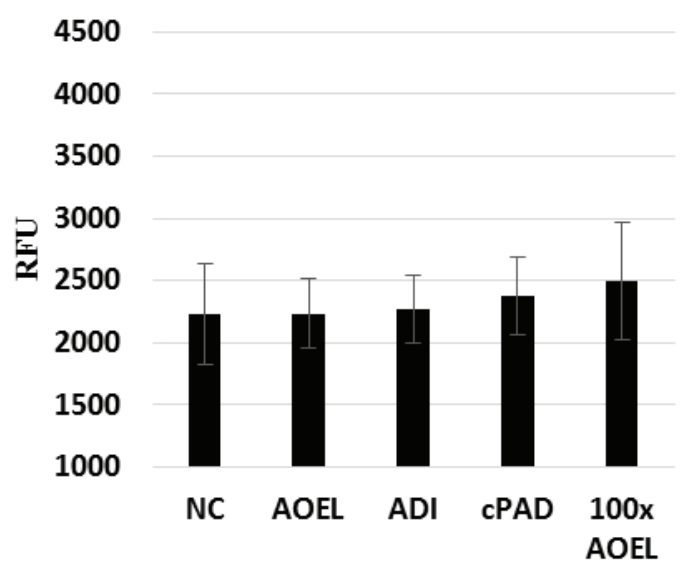

since this organ plays a major role in the biotransformation and detoxification of toxic substances.

Possible reasons why we did not observe increased lipid peroxidation are that glyphosate is not capable of crossing the lipid membrane without the help of carriers or open ion channels (76) and that the route of exposure (oral gavage) and tested doses were too low to ensure enough bioavailability for lipid peroxidation. On the other hand, Astiz et al. (77) administered the compound via i.p. route which ensured higher bioavailability and resulted in increased lipid peroxidation.

As demonstrated by Mesnage et al. (35), El Shenawy et al. (67), and Slaninova et al. (78), liver glutathione is often depleted after short-term oxidative stress but elevated

liver

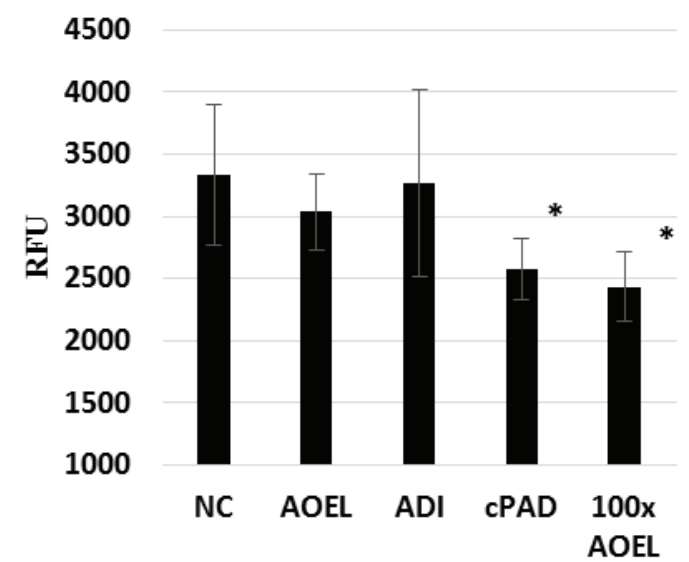

Figure 5 GSH activity in the plasma and liver tissue of Wistar rats receiving different glyphosate doses over 28 days. Statistical significance was set at $p<0.05$. *Significantly different from the negative control. NC-negative control receiving $1 \mathrm{~mL}$ of PBS; AOEL

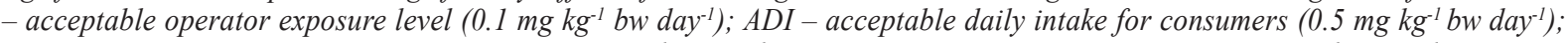
cPAD - chronic population adjusted dose $\left(1.75 \mathrm{mg} \mathrm{kg}^{-1} \mathrm{bw}\right.$ day-1); 100xAOEL - 100 times the AOEL $\left(10 \mathrm{mg} \mathrm{kg}^{-1} \mathrm{bw} \mathrm{day}^{-1}\right)$ 
after long-term exposure to oxidants. Low glyphosate doses we tested did not produce significant changes in the GSH level. In the study of El Shenawy et al. (67), higher glyphosate availability after one and two weeks of i.p. treatment with 135 and $270 \mathrm{mg} \mathrm{kg}^{-1}$ in rats every other day caused a decrease in liver GSH vs. control samples. Mesnage et al. (35) also found slightly decreased liver GSH in a two-year study of female Sprague-Dawley rats receiving $4 \mathrm{ng} \mathrm{kg}^{-1} \mathrm{bw}$ of a glyphosate equivalent in a pesticide formulation Roundup through drinking water a day. They also observed lower levels of cysteine and increased levels of gamma-glutamyl dipeptides, which suggests that the two-year exposure led to a redistribution of cellular cysteine stores toward glutathione synthesis.

In our study, glyphosate at higher doses stimulated the antioxidant defence system by increasing the activity of GSH-Px in the liver. This is in line with several other studies reporting increased GSH-Px $(20,79,80)$ after glyphosate treatment. Our findings are also in line with Alp et al. (81), who demonstrated that daily exposure of Wistar rats to lower glyphosate doses ( $4 \mathrm{mg} \mathrm{kg}^{-1} \mathrm{bw}$ ) lowered the total antioxidant status. Larsen et al. (24), in turn, demonstrated enhanced metabolic activity of selenium-independent GPx in kidneys and small intestines, but not in the liver after 90 days exposure to glyphosate.

\section{Cholinesterase activity in plasma}

Figure 7 shows the effects of glyphosate on rat plasma ChE activities. Glyphosate did not significantly affect total ChE, even though it dropped by about $35 \%$ in the AOEL and ADI groups compared to control. The only significant difference was between the ADI and the 100xAOEL group.

AChE activity in turn, did drop significantly in the AOEL and ADI group compared to control.

$\mathrm{BChE}$ varied across the groups, but the only significant difference was between the ADI and the 100xAOEL group.
Inhibition of acetylcholinesterase (AChE) activity as a toxicological endpoint of glyphosate has been a matter of debate. Although it is structurally related to organophosphates, glyphosate lacks a specific chemical group such as a halide, sulphur, or thiocyanate group on the phosphorus atom to bind to the active centre of AChE. For the US EPA(5), this fact was a sufficient reason not to assess the neurotoxicological effects of glyphosate. But in 2009, the US EPA changed their mind (45) and called for acute and subchronic neurotoxicity studies, whose findings are due this year. Several independent reports, however, have shown AChE inhibition in non-mammalian species by environmentally relevant doses of glyphosate $(28,82-88)$. At low concentrations, glyphosate seems to cause neurotoxic effects indirectly, that is, through the glycine in its chemical structure, which is also part of different proteins, enzymes, and mechanisms in the body. As an analogue to glycine, glyphosate can affect AChE in two ways: by interfering with the synthesis of glycogen synthase kinase 3, whose overexpression can inhibit acetylcholine synthesis $(2,89)$ or by decreasing the synthesis of hormonesensitive lipases (again glycine substituents) that are distantly related to $\mathrm{AChE}$ levels $(2,89)$. So far, only our study and the study of Larsen et al. (89) have demonstrated AChE inhibition in rats, with the difference that the inhibition in our study was significant with the two lowest doses.

Our study suggests that sub-chronic exposure to glyphosate mostly affects DNA in the liver and white blood cells. We have not confirmed general oxidative stress, while total cholinesterase activity showed some, yet inconsistent, deviations from control. Consistent, however, was significantly diminished $\mathrm{AChE}$ activity with all tested doses.

The discrepancy between our and other reported findings may primarily be owed to different exposure routes, treatment duration, and glyphosate doses used. Still, some

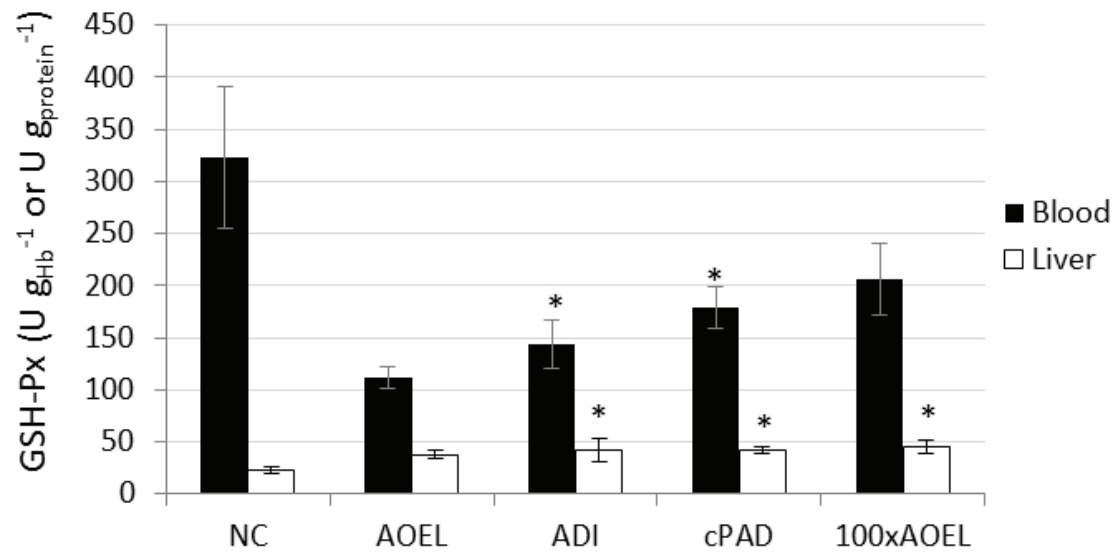

Figure 6 GSH-Px activity in the whole blood and liver tissue of Wistar rats receiving different glyphosate doses over 28 days. Statistical significance was set at $p<0.05$. *Significantly different from the negative control. NC-negative control receiving $1 \mathrm{~mL}$ of PBS; AOEL

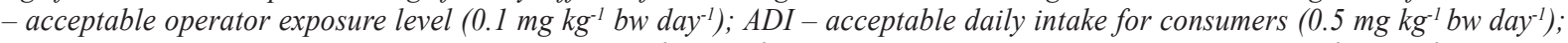
cPAD - chronic population adjusted dose $\left(1.75 \mathrm{mg} \mathrm{kg}^{-1} \mathrm{bw}\right.$ day-1); 100xAOEL - 100 times the AOEL $\left(10 \mathrm{mg} \mathrm{kg}^{-1} \mathrm{bw} \mathrm{day}^{-1}\right)$ 

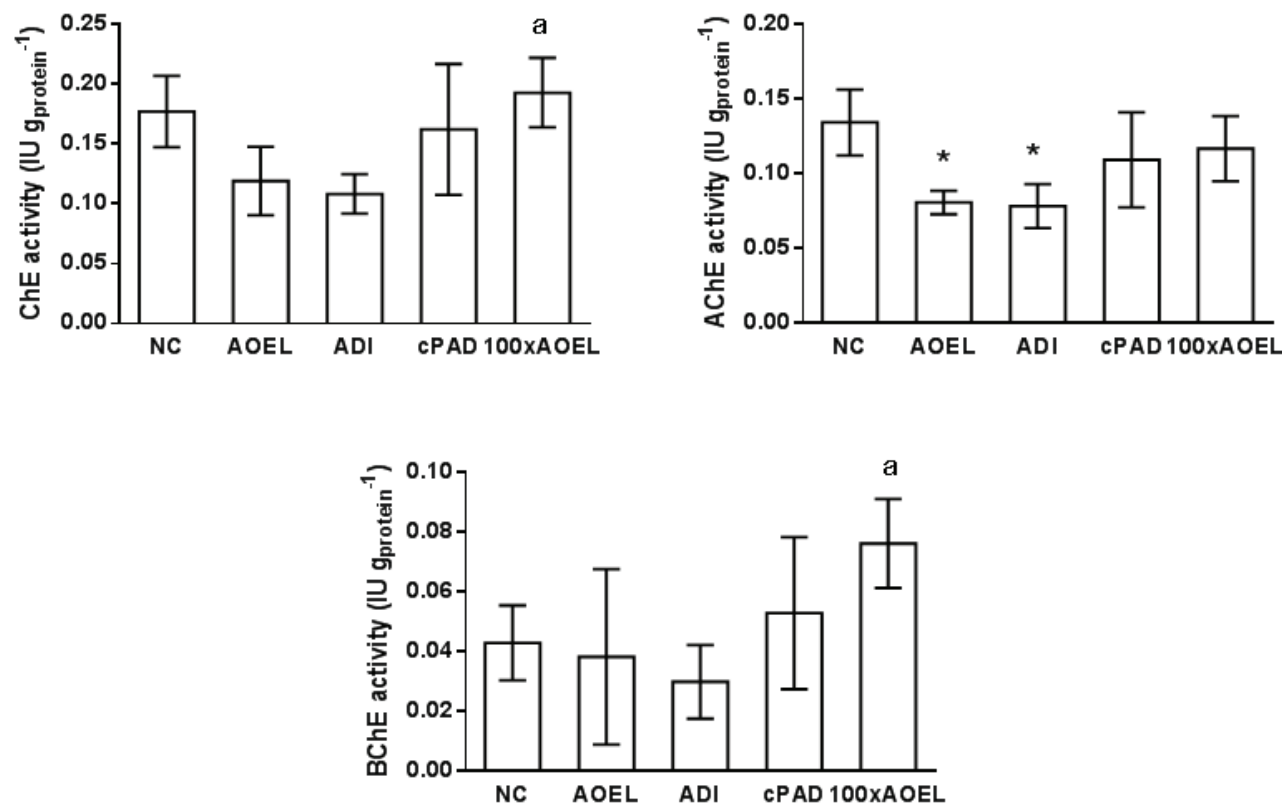

Figure 7 Changes in ChE, AChE, and BChE activity in the plasma of Wistar rats receiving different glyphosate doses over 28 days. The results are shown as mean and $S D$ values. Significantly different values $(P<0.05)$ were: $(*)$ compared to control, (a) compared to $A D I$. NC-negative control receiving $1 \mathrm{~mL}$ of PBS; AOEL - acceptable operator exposure level $\left(0.1 \mathrm{mg} \mathrm{kg}^{-1} \mathrm{bw} \mathrm{day-1}^{-1}\right)$; ADI-acceptable daily intake for consumers $\left(0.5 \mathrm{mg} \mathrm{kg}^{-1} \mathrm{bw}\right.$ day $\left.{ }^{-1}\right) ; c P A D$ - chronic population adjusted dose $\left(1.75 \mathrm{mg} \mathrm{kg}^{-1} \mathrm{bw} \mathrm{day-1}^{-1}\right) ; 100 x A O E L-100$ times the AOEL (10 $\mathrm{mg} \mathrm{kg}^{-1} \mathrm{bw}$ day $\left.^{-1}\right)$

reports $(2,35,46,83)$, like ours, suggest that glyphosate may produce harmful effects even at low doses. As for exposure duration, several short-term studies did not demonstrate toxic effects (as reviewed in 32), but lifelong exposure was associated with kidney and liver toxicity in rats (33-35). Higher toxicity was also reported for subchronic and chronic exposure $(35,37)$.

Exposure route entails another set of issues to consider. Intravenous (i.v.) and intraperitoneal (i.p.) routes used in earlier studies resulted in much higher bioavailability of the tested compound than the oral route (43). We, however, opted for oral exposure as the most likely exposure route in humans. When a tested compound is administered orally, as glyphosate was in our study, its metabolism also has to be taken into account, as it can produce even more reactive and toxic substances.

However, only $6 \%$ of the parent glyphosate compound administered orally is transformed into its first pass metabolites aminomethylphosphonic acid (AMPA), $N$-methyl AMPA, and $N$-acetylglyphosate $(42,43)$ and both glyphosate and AMPA have a similar half-day elimination rate (43). Another thing to consider is glyphosates poor absorption through the gastrointestinal tract. Almost $90 \%$ of glyphosate is excreted unchanged through faeces or urine in 72 hours, while $1 \%$ persists in the tissues, colon and bone in particular, even after seven days (42). This points to the risk of its bioaccumulation, which could affect the results of some of the analytical methods used, such as the alkaline comet assay. The treatment schedule we applied caused a constant delivery of new amounts of the tested compound. This means that the parent compound and its metabolites constantly induced primary DNA damage. The level of DNA damage we measured, therefore, represents the sum of both direct and repair-induced DNA lesions, since after 28 days equilibrium between DNA damage infliction and repair might occur.

Our study also has some limitations. Since the comet assay pointed only to the primary DNA damage, further studies are needed before we can draw a general conclusion about glyphosate genotoxicity. These studies should focus on biomarkers that provide more insight into aneugenic effects, epigenetic mechanisms of DNA damage, and cellcycle disturbances. Furthermore, we did not assess inflammatory processes as possible confounders involved in hepatocellular damage, which were noticed in previous studies. For instance, Kumar et al. (90) and Tang et al. (66) demonstrated that glyphosate exposure increased mRNA expression of inflammatory parameters and concluded that glyphosate-induced liver toxicity is mediated by inflammation, oxidative stress, and lipid-related pathways. All this remains to be proven in future studies.

\section{CONCLUSION}

Exposure to environmentally relevant glyphosate levels, presumably not harmful to humans, seems to have different effects from exposure to much higher glyphosate doses (our 100xAOEL and doses reported elsewhere), especially where oxidative stress is concerned. We have demonstrated that, even without oxidative stress, small doses (allowed for human exposure) can produce significant primary DNA 
damage and inhibit $\mathrm{AChE}$, which may both be related to indirect action through glycine substitution. In fact, our study suggests that the mechanisms of action depend on the exposure dose and that a new approach is needed to study the effects of small chronic and sub-chronic exposure, which has also been suggested by Mesnage et al. (35). Even though we are far from the conclusion about whether small doses in subchronic and chronic exposures are safe, a risk for human health certainly cannot be excluded.

\section{Acknowledgement}

This work was financially supported by Project Organic Pollutants_in Environment - Markers and Biomarkers of Toxicity (OPENTOX), funded by the Croatian Science Foundation (grant number 8366).

\section{Conflicts of interest}

None to declare.

\section{REFERENCES}

1. Duke SO, Powles SB. Glyphosate: a once-in-a-century herbicide. Pest Manag Sci 2008;64:319-25. doi: 10.1002/ ps. 1518

2. Samsel A, Seneff S. Glyphosate, pathways to modern diseases III: Manganese, neurological diseases, and associated pathologies. Surg Neurol Int 2015;6:45. doi: 10.4103/21527806.153876

3. De María N, Becerril JM, García-Plazaola J, Hernández A, De Felipe MR, Fernández-Pascual M. New insights on glyphosate mode of action in nodular metabolism: Role of shikimate accumulation. J Agr Food Chem 2006;54:2621-8. doi: 10.1021/ jf058166c

4. Richards TA, Dacks JB, Campbell SA, Blanchard JL, Foster PG, McLeod R, Roberts CW. Evolutionary origins of the eukaryotic shikimate pathway: Gene fusions, horizontal gene transfer, and endosymbiotic replacements. Eukaryot Cell 2006;5:1517-31. doi: 10.1128/EC.00106-06

5. US Environmental Protection Agency (US EPA). Reregistration Eligibility Decision (RED) Glyphosate. Prevention, Pesticides, and Toxics Substances, 1993;EPA-738-R-93-014, EPA738-F-93-011 [displayed 18 February 2018]. Available at https:// www3.epa.gov/pesticides/chem_search/reg_actions/ reregistration/red_PC-417300_1-Sep-93.pdf

6. Street RW, Serdy FS, Conkin RA, Kimball SL. Acute toxicity studies submitted in support of the registration of Roundup Herbicide. Roundup EPA Registration No. 524-308. Glyphosate Technical. R.D. No. 263, 1979.

7. German Federal Agency CPFS. Monograph on Glyphosate by the German Federal Agency for Consumer Protection and Food Safety. Annex B-5: Toxicology and metabolism, 1998. [displayed 18 February 2018]. Available at https://www.scribd. com/document/57155616/VOLUME3-1-GLYPHOSAT-05

8. European Food Safety Authority (EFSA). Conclusion on the peer review of the pesticide risk assessment of the active substance glyphosate. EFSA J 2015;13:4302. doi: 10.2903/j. efsa.2015.4302

9. Horth H, Blackmore K. Survey of glyphosate and AMPA in groundwaters and surface waters in Europe. Report by WRc plc, Swindon, Wiltshire, United Kingdom No: UC8073 2. 2009 [displayed 18 February 2018]. Available at http://www.egeis. org/cd-info/WRC-report-UC8073-02-December-2009Glyphosate-monitoring-in-water.pdf

10. McQueen H, Callan AC, Hinwood AL. Estimating maternal and prenatal exposure to glyphosate in the community setting. Int J Hyg Envir Heal 2012;215:570-6. doi: 10.1016/j. ijheh.2011.12.002

11. US Environmental Protection Agency (US EPA). Glyphosate: Chronic Dietary Exposure Assessment for the Section 3 Registration Action. PC Code 103601, DP Number 321666, 2006 [displayed 18 February 2018]. Available at https://archive. epa.gov/pesticides/chemicalsearch/chemical/foia/web/ pdf/103601/103601-2006-05-08a.pdf

12. Séralini G-E, Clair E, Mesnage R, Gress S, Defarge N, Malatesta M, Hennequin D, de Vendômois JS. Republished study: longterm toxicity of a Roundup herbicide and a Roundup-tolerant genetically modified maize. Environ Sci Eur 2014;26:14. doi: 10.1186/s12302-014-0014-5

13. World Health Organization (WHO), International Agency for Research Cancer (IARC). Some Organophosphate Insecticides and Herbicides. Glyphosate. IARC Monographs on the Evaluation of Carcinogenic Risks to Humans. Vol. 112, 2017 [displayed 18 February 2018]. Available at http://monographs. iarc.fr/ENG/Monographs/vol112/mono112.pdf

14. Guyton KZ, Loomis D, Grosse Y, El Ghissassi F, BenbrahimTallaa L, Guha N, Scoccianti C, Mattock H, Straif K; International Agency for Research on Cancer Monograph Working Group, IARC, Lyon, France. Carcinogenicity of tetrachlorvinphos, parathion, malathion, diazinon, and glyphosate. Lancet Oncol 2015;16:490-1. doi: 10.1016/S14702045(15)70134-8

15. European Food Safety Authority (EFSA). Peer review of the pesticide risk assessment of the potential endocrine disrupting properties of glyphosate. EFSA J 2017;15:4979. doi: 10.2903/j. efsa.2017.4979

16. FAO-WHO. Joint FAO/WHO Meeting on Pesticide Residues (JMPR) [displayed 18 February 2018]. Available at http://www. who.int/foodsafety/areas_work/chemical-risks/jmpr/en/

17. European Commission (EC). Glyphosate, 2017 [displayed 18 February 2018] Available at https://ec.europa.eu/food/plant/ pesticides/glyphosate_en

18. Williams GM, Kroes R, Munro IC. Safety evaluation and risk assessment of the herbicide Roundup and its active ingredient, glyphosate, for humans. Regul Toxicol Pharm 2000;31:117-65. doi: 10.1006/rtph.1999.1371

19. Tarazona JV, Court-Marques D, Tiramani M, Reich H, Pfeil R, Istace F, Crivellente F. Glyphosate toxicity and carcinogenicity: a review of the scientific basis of the European Union assessment and its differences with IARC. Arch Toxicol 2017;91:2723-2743. doi: 10.1007/s00204-017-1962-5.

20. Bababunmi EA, Olorunsogo OO, Bassir O. The uncoupling effect of $N$-(phosphonomethyl)glycine on isolated rat liver mitochondria. Biochem Pharmacol 1979;28:925-7. doi: 10.1016/0006-2952(79)90377-0

21. Olorunsogo OO, Bababunmi EA, Bassir O. Effect of glyphosate on rat liver mitochondria in vivo. B Environ Contam Tox 1979;22:357-64. doi: 10.1007/BF02026955

22. Olorunsogo OO. Modification of the transport of protons and $\mathrm{Ca}^{2+}$ ions across mitochondrial coupling membrane by $N$-(phosphonomethyl)glycine. Toxicology 1990;61:205-9. doi: 10.1016/0300-483X(90)90021-8 
23. Ugarte R. Interaction between glyphosate and mitochondrial succinate dehydrogenase. Comput Theor Chem 2014;1043:54 63. doi: 10.1016/j.comptc.2014.05.018

24. Larsen K, Najle R, Lifschitz A, Virkel G. Effects of sub-lethal exposure of rats to the herbicide glyphosate in drinking water: Glutathione transferase enzyme activities, levels of reduced glutathione and lipid peroxidation in liver, kidneys and small intestine. Environ Toxicol Phar 2012;34:811-8. doi: 10.1016/j. etap.2012.09.005

25. Banerjee BD, Seth V, Bhattacharya A, Pasha ST, Chakraborty AK. Biochemical effects of some pesticides on lipid peroxidation and free-radical scavengers. Toxicol Lett 1999;107:33-47. doi: 10.1016/S0378-4274(99)00029-6

26. Richard S, Moslemi S, Sipahutar H, Benachour N, Seralini GE. Differential effects of glyphosate and Roundup on human placental cells and aromatase. Environ Health Persp 2005;113:716-20. doi: 10.1289/ehp.7728

27. Lushchak OV, Kubrak OI, Storey JM, Storey KB, Lushchak VI. Low toxic herbicide Roundup induces mild oxidative stress in goldfish tissues. Chemosphere 2009;76:932-7. doi: 10.1016/j. chemosphere.2009.04.045

28. Modesto KA, Martinez CBR. Roundup ${ }^{\circledR}$ causes oxidative stress in liver and inhibits acetylcholinesterase in muscle and brain of the fish Prochilodus lineatus. Chemosphere 2010;78:294-9. doi: 10.1016/j.chemosphere.2009.10.047

29. Modesto KA, Martinez CBR. Effects of Roundup Transorb on fish: Hematology, antioxidant defenses and acetylcholinesterase activity. Chemosphere 2010;81:781-7. doi: 10.1016/j. chemosphere.2010.07.005

30. Jasper R, Locatelli GO, Pilati C, Locatelli C. Evaluation of biochemical, hematological and oxidative parameters in mice exposed to the herbicide glyphosate-Roundup ${ }^{\circledR}$. Interdiscip Toxicol 2012;5:133-40. doi: 10.2478/v10102-012-0022-5

31. El-Demerdash FM, Yousef MI, Elagamy EI. Influence of paraquat, glyphosate, and cadmium on the activity of some serum enzymes and protein electrophoretic behavior (in vitro). J Environ Sci Heal B 2001;36:29-42. doi: 10.1081/PFC100000914

32. Smith EA, Oehme FW. The biological activity of glyphosate to plants and animals: A literature review. Vet Hum Toxicol 1992;34:531-43. PMID: 1287975

33. Dallegrave E, Mantese FDG, Coelho RS, Pereira JD, Dalsenter PR, Langeloh A. The teratogenic potential of the herbicide glyphosate-Roundup ${ }^{\circledR}$ in Wistar rats. Toxicol Lett 2003;142:4552. doi: 10.1016/S0378-4274(02)00483-6

34. Benedetti AL, Vituri CDL, Trentin AG, Domingues MAC, Alvarez-Silva M. The effects of sub-chronic exposure of Wistar rats to the herbicide Glyphosate-Biocarb ${ }^{\circledR}$. Toxicol Lett 2004;153:227-32. doi: 10.1016/j.toxlet.2004.04.008

35. Mesnage R, Renney G, Séralini GE, Ward M, Antoniou MN. Multiomics reveal non-alcoholic fatty liver disease in rats following chronic exposure to an ultra-low dose of Roundup herbicide. Sci Rep-UK 2017;7:39328. doi: 10.1038/srep39328

36. Annett R, Habibi HR, Hontela A. Impact of glyphosate and glyphosate-based herbicides on the freshwater environment. J Appl Toxicol 2014;34:458-79. doi: 10.1002/jat.2997

37. Bai SH, Ogbourne SM. Glyphosate: environmental contamination, toxicity and potential risks to human health via food contamination. Environ Sci Pollut R 2016;23:18988-9001. doi: 10.1007/s11356-016-7425-3

38. Colvin LB, Miller JA. Residue and metabolism. The dynamics of accumulation and depletion of orally ingested
$N$-phosphonylmethylglycine-14C. Unpublished report Monsanto Company, St Louis, MO 1973 [displayed 18 February 2018]. Available at http://www.inchem.org/documents/jmpr/ jmpmono/v86pr08.htm???

39. Ridley WP, Mirley K. The metabolism of glyphosate in SpragueDawley rats. Part I. Excretion and tissue distribution of glyphosate and its metabolites following intravenous and oral administration. Study number 86139 , project number mL-86438 (March 1988) Unpublised report Monsanto Environ Heal Lab St Louis, MO. 1988. Subbmited to WHO by Monsanto Int. Services SA, Brussel, Belgium-in WHO: Pesticide residues in the food 2004 part II, Joint FAO/WHO Meeting on pesticide Residues, IPCS, 2004 [displayed 18 February 2018] Available at https://books.google.hr/books?id=Q8qhjfKFMf4C\&pg=PA $95 \& \mathrm{dq}=\mathrm{Pes}$ ticide+Residues + in + Food + $+2004:+$ Evaluations $+2004,+$ Toxic

40. Howe RH, Chott RC, McClanahan RH. Metabolism of glyphosate in Sprague-Dawley rats. Part II: Identification, characterization, and quantitation of glyphosate and its metabolites after intravenous and oral administration. Unpublished report no. MSL-7206, RD No. 877, 1988, submitted to U.S. Environmental Protection Agency by Monsanto Company. Reregistration Eligibility Decision (RED) Glyphosate; EPA-738-F-93-011;U.S. Environmental Protection Agency, Office of Prevention, Pesticides, and Toxic Substances, Office of Pesticide Programs, U.S. Government Printing Office: Washington, DC, 1993. [displayed 18 February 2018] Available at https://www3.epa.gov/pesticides/chem_search/reg_actions/ reregistration/red_PC-417300_1-Sep-93.pdf

41. National Toxicology Program (NTP). Technical Report on Toxicity Studies of Glyphosate (CAS No. 1071-83-6) Administered in Dosed Feed to F344/N rats and B6C3F1 Mice. NIH Publ 92-3135. 1992 [displayed 18 February 2018]. Available athttps://ntp.niehs.nih.gov/ntp/htdocs/st_rpts/tox016. pdf

42. Brewster DW, Warren J, Hopkins II WE. Metabolism of glyphosate in Sprague-Dawley rats: tissue distribution, identification, and quantitation of glyphosate-derived materials following a single oral dose. Fund Appl Toxicol 1991;17:43-51. doi: 10.1016/0272-0590(91)90237-X

43. Anadón A, Martínez-Larrañaga MR, Martínez MA, Castellano VJ, Martínez M, Martin MT, Nozal MJ, Bernal JL. Toxicokinetics of glyphosate and its metabolite aminomethyl phosphonic acid in rats. Toxicol Lett 2009;190:91-5. doi: 10.1016/j. toxlet.2009.07.008

44. California Environmental Protection Agency Department of Pesticide Regulation Human Health Assessment Branch. Summary of Toxicology Data Glyphosate, 2015 [displayed 18 February 2018]. Available at http://www.cdpr.ca.gov/docs/risk/ toxsums/pdfs/1855.pdf

45. US Environmental Protection Agency (US EPA). Glyphosate Issue Paper: Evaluation of Carcinogenic Potential, 2016 [displayed 18 February 2018] Available at https://www.epa.gov/ sites/production/files/2016-09/documents/glyphosate_issue paper_evaluation_of_carcincogenic_potential.pdf

46. Kašuba V, Milić M, Rozgaj R, Kopjar N, mLadinić M, Žunec S, Lucić Vrdoljak A, Pavičić I, Čermak AM, Pizent A, Tariba Lovaković B, Želježić D. Effects of low doses of glyphosate on DNA damage, cell proliferation and oxidative stress in the HepG2 cell line. Environ Sci Pollut R 2017;24:19267-81. doi: 10.1007/s11356-017-9438-y 
47. King JJ, Wagner RS. Toxic effects of the herbicide Roundup regular on pacific northwestern amphibians. Northwest Nat 2010;91:318-24. doi: 10.1898/NWN09-25.1

48. Curwin BD, Hein MJ, Sanderson WT, Striley C, Heederik D, Kromhout H, Reynolds SJ, Alavanja MC. Urinary pesticide concentrations among children, mothers and fathers living in farm and non-farm households in Iowa. Ann Occup Hyg 2007;51:53-65. doi: 10.1093/annhyg/mel062

49. Niemann L, Sieke C, Pfeil R, Solecki R. A critical review of glyphosate findings in human urine samples and comparison with the exposure of operators and consumers. J Verbrauch Lebensm 2015;10:3-12. doi: 10.1007/s00003-014-0927-3

50. Acquavella JF, Alexander BH, Mandel JS, Gustin C, Baker B, Chapman P. Glyphosate biomonitoring for farmers and their families: Results from the farm family exposure study. Environ Health Persp 2004;112:321-6. doi: 10.1289/ehp.6667

51. de Araujo JSA, Delgado IF, Paumgartten FJR. Glyphosate and adverse pregnancy outcomes, a systematic review of observational studies. BMC Public Health 2016;16:472. doi: 10.1186/s12889-016-3153-3

52. Aris A, Leblanc S. Maternal and fetal exposure to pesticides associated to genetically modified foods in Eastern Townships of Quebec, Canada. Reprod Toxicol 2011;31:528-33. doi: 10.1016/j.reprotox.2011.02.004

53. Al-Rajab AJ, Schiavon M. Degradation of ${ }^{14} \mathrm{C}$-glyphosate and aminomethylphosphonic acid (AMPA) in three agricultural soils. J Environ Sci-China 2010;22:1374-80. doi: 10.1016/S10010742(09)60264-3

54. European Food Safety Authority (EFSA). Endorsed for Public Consultation Draft Scientific Opinion. Scientific opinion on genotoxicity testing strategies applicable to food and feed safety assessment, . 2011 [displayed 18 February 2018]. Available at https:/www.efsa.europa.eu/sites/default/files/consultation/ scaf110420\%2C0.pdf

55. Pant K, Springer S, Bruce S, Lawlor T, Hewitt M, Asrdema MJ. Vehicle and positive control values fromthe in vivo rodent comet assay and biomonitoring studies using human lymphocytes: historical database and influence of technical aspects. Environ Mol Mutagen 2014;55:633-42. doi: 10.1002/em.21881

56. Peraica M, Ljubanović D, Domijan A-M. The effect of a single dose of fumonisin B1 on rat kidney. Croat Chem Acta 2008;81:119-24.

57. Recio L, Hobbs C, Caspary W, Witt KL. Dose-response assessment of four genotoxic chemicals in a combined mouse and rat micronucleus (MN) and Comet assay protocol. J Toxicol Sci 2010;35:149-62. PMCID: PMC3520611

58. Smith CC, Adkins DJ, Martin EA, O'Donovan MR. Recommendations for design of the rat comet assay. Mutagenesis 2008;23:233-40. doi: 10.1093/mutage/gen008

59. McNamee JP, Bellier P V. Use of a standardized JaCVAM in vivo rat comet assay protocol to assess the genotoxicity of three coded test compounds; ampicillin trihydrate, 1 , 2-dimethylhydrazine dihydrochloride, and $N$-nitrosodimethylamine. Mutat Res Gen Tox En 2015;786788:158-64. doi: 10.1016/j.mrgentox.2015.02.005

60. Drury JA, Nycyk JA, Cooke RWI. Comparison of urinary and plasma malondialdehyde in preterm infants. Clin Chim Acta1997;263:177-85. doi: 10.1016/S0009-8981(97)00051-X

61. Kamencic H, Lyon A, Paterson PG, Juurlink BHJ. Monochlorobimane fluorometric method to measure tissue glutathione. Anal Biochem 2000;286:35-7. doi: 10.1006/ abio. 2000.4765
62. Belsten J, Wright A. European Community: FLAIR common assay for whole-blood glutathione peroxidase (GSH-Px); results of an inter-laboratory trial. Eur J Clin Nutr 1995;49:921-7. PMID: 8925794

63. Bradford MM. A rapid and sensitive method for the quantitation of microgram quantities of protein utilizing the principle of protein-dye binding. Anal Biochem 1976;72:248-54. doi: 10.1016/0003-2697(76)90527-3

64. Ellman GL, Courtney KD, Andres V, Featherstone RM. A new and rapid colorimetric determination of acetylcholinesterase activity. Biochem Pharmacol 1961;7:88-95. doi: 10.1016/00062952(61)90145-9

65. Moser VC, Simmons JE, Gennings C. Neurotoxicological interactions of a five-pesticide mixture in preweanling rats. Toxicol Sci 2006;92:235-45. doi: 10.1093/toxsci/kfj189

66. Tang J, Hu P, Li Y, Win-Shwe TT, Li C. Ion imbalance is involved in the mechanisms of liver oxidative damage in rats exposed to glyphosate. Front Physiol 2017;8:1-12. doi: 10.3389/ fphys.2017.01083

67. El-Shenawy NS. Oxidative stress responses of rats exposed to Roundup and its active ingredient glyphosate. Environ Toxicol Pharmacol 2009;28:379-85. doi: 10.1016/j.etap.2009.06.001

68. Çağlar S, Kolankaya D. The effect of sub-acute and sub-chronic exposure of rats to the glyphosate-based herbicide Roundup. Environ Toxicol Phar 2008;25:57-62. doi: 10.1016/j. etap.2007.08.011

69. Alvarez-Moya C, Silva MR, Ramírez CV, Gallardo DG, Sánchez $\mathrm{RL}$, Aguirre AC, Velasco AF. Comparison of the in vivo and in vitro genotoxicity of glyphosate isopropylamine salt in three different organisms. Genet Mol Biol 2014;37:105-10. PMID: 24688297

70. Mladinić M, Berend S, Lucić Vrdoljak A, Kopjar N, Radić B, Želježić D. Evaluation of genome damage and its relation to oxidative stress induced by glyphosate in human lymphocytes in vitro. Environ Mol Mutagen 2009;50:800-7. doi: 10.1002/ em.20495

71. Mañas F, Peralta L, Raviolo J, Ovando HG, Weyers A, Ugnia L, Cid MG, Larripa I, Gorla N. Genotoxicity of glyphosate assessed by the comet assay and cytogenetic tests. Environ Toxicol Phar 2009;28:37-41. doi: 10.1016/j.etap.2009.02.001

72. Manas F, Peralta L, Ugnia L, Weyers A, Garcia Ovando H, Gorla $\mathrm{N}$. Oxidative stress and comet assay in tissues of mice administered glyphosate and AMPA in drinking water for 14 days. BAG - J Basic Appl Genet. 2013;24:67-75 [displayed 18 February 2018] Available at http://www.scielo.org.ar/scielo. php? script=sci_arttext\&pid=S 1852 62332013000300007\&lng=es.

73. Bolognesi C, Bonatti S, Degan P, Gallerani E, Peluso M, Rabboni R, Roggieri P, Abbondandolo A. Genotoxic activity of glyphosate and its technical formulation Roundup. J Agr Food Chem 1997;45:1957-62. doi: 10.1021/j99606518

74. Peluso M, Munnia A, Bolognesi C PS. 32P-postlabeling detection of DNA adducts in mice treated with the herbicide Roundup. Env Mol Mutagen 1998;31:55-9. PMID: 9464316

75. Greim H, Saltmiras D, Mostert V, Strupp C. Evaluation of carcinogenic potential of the herbicide glyphosate, drawing on tumor incidence data from fourteen chronic/carcinogenicity rodent studies. Crit Rev Toxicol 2015;45:185-208. doi: 10.3109/10408444.2014.1003423

76. Peixoto F. Comparative effects of the Roundup and glyphosate on mitochondrial oxidative phosphorylation. Chemosphere 2005;61:1115-22. doi: 10.1016/j.chemosphere.2005.03.044 
77. Astiz M, de Alaniz MJT, Marra CA. Effect of pesticides on cell survival in liver and brain rat tissues. Ecotoxicol Environ Saf 2009;72:2025-32. doi: 10.1016/j.ecoenv.2009.05.001

78. Slaninova A, Smutna M, Modra H, Svobodova Z. A review: oxidative stress in fish induced by pesticides. Neuro Endocrinol Lett 2009;30(Suppl 1):2-12. PMID: 20027135

79. Beuret CJ, Zirulnik F, Giménez MS. Effect of the herbicide glyphosate on liver lipoperoxidation in pregnant rats and their fetuses. Reprod Toxicol 2005;19:501-4 doi: 10.1016/j. reprotox.2004.09.009

80. Abarikwu SO, Akiri OF, Durojaiye MA, Adenike A. Combined effects of repeated administration of Bretmont Wipeout (glyphosate) and Ultrazin (atrazine) on testosterone, oxidative stress and sperm quality of Wistar rats. Toxicol Mech Method 2015;25:70-80. doi: 10.3109/15376516.2014.989349

81. Alp H, Pinar N, Dokuyucu R, Kaplan I, Sahan M, Senol S, Karakus A,Yaldiz M. Effects of intralipid and caffeic acid phenyl esther (CAPE) against hepatotoxicity and nephrotoxicity caused by glyphosate isopropylamine (GI). Eur J Inflamm 2016;14:39. doi: $10.1177 / 1721727 X 16630318$

82. Cattaneo R, Clasen B, Loro VL, De Menezes CC, Pretto A, Baldisserotto B, Santi A, de Avila LA. Toxicological responses of Cyprinus carpio exposed to a commercial formulation containing glyphosate. Bull Environ Contam Toxicol 2011;87:597-602. doi: 10.1007/s00128-011-0396-7

83. Lajmanovich RC, Attademo AM, Peltzer PM, Junges CM, Cabagna MC. Toxicity of four herbicide formulations with glyphosate on Rhinella arenarum (Anura: Bufonidae) tadpoles: B-esterases and glutathione S-transferase inhibitors. Arch Environ Con Tox 2011;60:681-9. doi: 10.1007/s00244-0109578-2

84. Glusczak L, dos Santos Miron D, Crestani M, Braga da Fonseca M, de Araújo Pedron F, Duarte MF, Vieira VL. Effect of glyphosate herbicide on acetylcholinesterase activity and metabolic and hematological parameters in piava (Leporinus obtusidens). Ecotoxicol Environ Saf 2006;65:237-41. doi: 10.1016/j.ecoenv.2005.07.017

85. Salbego J, Pretto A, Gioda CR, de Menezes CC, Lazzari R, Radünz Neto J, Baldisserotto B, Loro VL. Herbicide formulation with glyphosate affects growth, acetylcholinesterase activity, and metabolic and hematological parameters in Piava (Leporinus obtusidens). Arch Environ Con Tox 2010;58:740-5. doi: 10.1007/s00244-009-9464-y

86. Glusczak L, dos Santos Miron D, Moraes BS, Simões RR, Schetinger MR, Morsch VM, Loro VL. Acute effects of glyphosate herbicide on metabolic and enzymatic parameters of silver catfish (Rhamdia quelen). Comp Biochem Phys C 2007;146:519-24. doi: 10.1016/j.cbpc.2007.06.004

87. Hoshi M, Takashima A, Noguchi K, Murayama M, Sato M, Kondo S, Saitoh Y, Ishiguro K, Hoshino T, Imahori K. Regulation of mitochondrial pyruvate dehydrogenase activity by tau protein kinase I/glycogen synthase kinase 3 beta in brain. Proc Natl Acad Sci USA. 1996;93:2719-23. PMCID: PMC39697

88. Kwiatkowska M, Paweł J, Bukowska B. Glifosat i jego preparaty - toksyczność, narażenie zawodowe i środowiskowe [Glyphosate and its formulations-toxicity, occupational and environmental exposure, in Polish]. Med Pr 2013;64:717-29. doi: 10.13075/ mp.5893.2013.0059

89. Larsen KE, Lifschitz AL, Lanusse CE, Virkel GL. The herbicide glyphosate is a weak inhibitor of acetylcholinesterase in rats. Environ Toxicol Phar 2016;45:41-4. doi: 10.1016/j. etap.2016.05.012

90. Kumar S, Khodoun M, Kettleson EM, McKnight C, Reponen T, Grinshpun SA, Adhikari A. Glyphosate-rich air samples induce IL-33, TSLP and generate IL-13 dependent airway inflammation. Toxicology 2014;325:42-51. doi: 10.1016/j. tox.2014.08.008

\section{Oksidacijski stres, aktivnost kolinesteraza i primarna oštećenja u jetri, krvi i plazmi Wistar štakora nakon 28-dnevnog izlaganja glifosatu}

U okviru 28-dnevnog pokusa istražili smo učinke herbicida glifosata na modelu odraslih mužjaka Wistar štakora koji su oralno dobivali testirani spoj u subletalnim dnevnim dozama: 0,1 od prihvatljive razine izloženosti operatera $(0,1 x A O E L)$, 0,5 od prihvatljivog dnevnog unosa za potrošače $(0,5 \times \mathrm{ADI}), 1,75$ (odgovara kroničnoj populacijskoj prilagođenoj dozi, cPAD) i $10 \mathrm{mg} \mathrm{kg}^{-1}$ tjelesne težine na dan (odgovara 100xAOEL). Tijekom pokusa praćeni su sistemski toksični učinci. Nakon završetka svih tretmana svakoj je pokusnoj životinji izmjerena tjelesna težina i težina jetre te su uspoređene $s$ polazišnim vrijednostima. Alkalnim komet-testom izmjerena je razina primarnih oštećenja DNA u leukocitima i jetrenim stanicama. Primjenom metoda za procjenu oksidacijskog stresa izmjerene su razine lipidne peroksidacije (TBARs), reaktivnih kisikovih vrsta (ROS) i glutationa $(\mathrm{GSH})$ te aktivnost enzima glutation peroksidaze (GSH-Px). Izmjerene su i aktivnosti ukupnih kolinesteraza (ChE), acetilkolinesteraze (AChE) i butirilkolinesteraze (BChE). Izloženi štakori imali su manje priraste težine od kontrolnih. Izloženost glifosatu uzrokovala je značajne poraste razine primarnih oštećenja DNA u jetrenim stanicama te malo manje u leukocitima. U svim izloženim skupinama izmjerene su niže vrijednosti TBARs u odnosu na kontrolu, sa značajno nižim vrijednostima u AOEL, ADI i cPAD skupinama u uzorcima jetre te $u$ AOEL i cPAD skupinama u uzorcima plazme. Aktivnost AChE bila je smanjena u svim tretmanima, s najnižom stopom nakon izlaganja dozi ADI. Aktivnost BChE blago je smanjena nakon izlaganja ADI, a povećana nakon izlaganja dozama cPAD i 100xAOEL. Ukupna aktivnost $\mathrm{ChE}$ te razine ROS/GSH u plazmi / jetri nisu se značajno razlikovale od kontrole, osim značajnog smanjenja jetrenog GSH nakon izlaganja dozama cPAD i 100xAOEL te 35-postotnog smanjenja aktivnosti ChE nakon izlaganja dozama AOEL i ADI. Aktivnost GSH-Px u krvi značajno je smanjena u AOEL i ADI tretmanu, a aktivnost GSH-Px u uzorcima jetre značajno je povećana u skupinama ADI, cPAD i 100xAOEL prema kontroli. Dobiveni rezultati pokazuju da čak i izloženost vrlo niskim dozama glifosata može izazvati mjerljive toksične učinke te upućuje na potrebu za promjenom pristupa procjeni rizika zbog kronične/subkronične izloženosti niskim dozama glifosata gdje oksidacijski stres ne mora nužno korelirati s razinom oštećenja DNA i inhibicijom acetilkolinesteraze.

KLJUČNE RIJEČI: ADI; aktivnost kolinesteraza; alkalni komet test; AOEL; cPAD; glutation; glutationska peroksidaza; lipidna peroksidacija; organofosforni pesticidi; ROS 